\title{
PENINGKATAN HASIL BELAJAR LAY UP BOLA BASKET MELALUI METODE MENGAJAR BAGIAN
}

\author{
Fajar Muhammad Faturahman $^{1 *}$, Beny Iskandar ${ }^{2}$,Eneng Fitri Amalia ${ }^{3}$ \\ Pendidikan Jasmani Kesehatan dan Rekreasi \\ Fakultas Keguruan dan Ilmu Pendidikan Universitas Suryakancana \\ Fajarmfaturahman@Gmail.Com
}

\begin{tabular}{l}
\hline \multicolumn{1}{c}{ Info Artikel } \\
\hline Sejarah Artikel: \\
Diterima Maret 2019 \\
Disetujui April 2019 \\
Dipublikasikan Juni 2019
\end{tabular}

Keyword:

Metode Bagian,

Keterampilan Teknik Dasar

Lay up Bola Basket.

\begin{abstract}
Abstrak
Penelitian ini dilatar belakangi oleh adanya fakta tentang kurangnya nilai siswa dalam praktik lay up pada pelajaran olahraga bola basket. Faktor keberhasilan teknik lay up salah satunya yaitu dengan pemilihan metode pengajaran, yang diajarkan di sekolah sudah banyak mengguanakan beberapa metode yang disesuaikan dengan kurikulum pendidikan jasmani, yang beberapa diantaranya kurang mampu meningkatkan keterampilan olahraga salahsatunya dibidang olahraga bola basket teknik lay up. Oleh karena itu, diperlukan penerapan metode pembelajaran yang mampu meningkatkan keterampilan teknik lay up bola basket pada siswa, yaitu melalui metode bagian. Tujuan dari penelitian ini adalah untuk dapat meningkatkan keterampilan teknik lay up bola basket pada siswa kelas VII-8 di SMP Negeri 1 Warungkondang melalui metode bagian. Metode yang digunakan adalah metode penelitian tindakan kelas. Subjek penelitian adalah siswa kelas VII-8 SMP Negeri 1 Warungkondang, yang terdiri atas 14 siswa laki-laki dan 18 siswi perempuan, dengan jumlah siswa keseluruhan 32 orang siswa. Instrument yang digunakan terdiri dari tes praktek berupa tes awal siklus dan tes akhir siklus dan non tes berupa lembar observasi siswa. Analisis data kuantitatif dalam penelitian ini menggunakan Microsoft excel. Hasil analisis penelitian menunjukkan bahwa terdapat peningkatan keterampilan teknik lay up bola basket pada siswa kelas VII8 SMP Negeri 1 Warungkondang melalui metode bagian.
\end{abstract}

\section{Abstrack}

This study is based on the existence fact the low score of layup technique at basketball lesson in sport class. One of the success key for lay-up practices are related to teaching methods. Meanwhile, half of all methods which are taught at school do not affect student skills eventhough it has adjusted by curriculum. Another method which can increase the layup technique students skill for basketball lesson such as "part method". Hence, the aim of this study is to increase the student skill at the basketball lesson for VIII grade student in middle high school, SMP N 1 Warungkondang. This class consists of 14 male students and 18 female students, so the total of students are 32 students. The instrument that was used are test method and non test method. Test method are in the form of cycle initial test and cycle final test. Another instrument is observation sheets for students as non test 
method. The analysis in this study used Microsoft Excel. The analysis result of students skill in basketball lesson at VIII grade 1 SMP Negeri 1 Warungkondangindicate an existence for increasing lay-up technique students after using part method at basketball lesson in sport class.

(C) 2019 Universitas Suryakancana

Alamat korespondensi:
E-mail: Adirahadian@unsur.ac.id
e-ISSN : 2721-7175 (online)

p-ISSN : 2089-2341 (cetak)

\section{PENDAHULUAN}

Pendidikan jasmani merupakan bagian penting bagi perkembangan manusia untuk mencapai tujuan pendidikan secara menyeluruh. Oleh karena itu, pendidikan jasmani bukan hanya merupakan sarana penunjang pendidikan saja, melainkan juga mewujudkan pembangunan bangsa.Dalam kurikulum pendidikan jasmani disekolahsekolah, olahraga cukup mendominasi materi pembelajaran. Padahal olahraga ini merupakan kegiatan fisik yang kompleks, termasuk didalamnya "close skill, open skill dan combination skill" bahkan tidak semua anak siap untuk menerimanya, untuk itu pengembangan dan modifikasi pembelajaran sangat penting untuk dilakukan agar tercapai tujuan pembelajaran yang diharapkan.

Didalam olahraga terdapat cabangcabang olahraga yang dapat dimainkan oleh masyarakat, baik di desa maupun di kota bahkan di sekolah dan instansi. Permainan bola basket saat ini mulai digemari oleh masyarakat Indonesia, dengan adanya kejuaraan basket seperti DBL, Campus League, WNBL, NBL, dll.
Menambah minat masyarakat untuk mempelajari olahraga basket dan mengikuti kejuaraan-kejuaraan tersebut. Hampir seluruh dunia mengenal dan memainkan olahraga basket ini, terutama di Amerika Utara, China dan juga benua Eropa. Tidak boleh dilupakan juga, kaum wanita pun tidak mau ketinggalan dibidang olahraga bola basket ini. Boleh dikatakan olahraga ini sudah sangat populer dan dikenal oleh segenap lapisan masyarakat.

Permainan bola basket ini sangat menarik, karena dapat dimainkan oleh semua golongan umur. Disamping itu juga karena dari para pemain dituntut keterampilan bermain, kesegaran fisik dan kekuatan daya tahan tubuh yang tinggi. (Vic Amber, 2009:4). Permainan bola basket merupakan permainan yang dimainkan oleh dua tim yang masingmasing terdiri dari 5 pemain. Tujuan dari kedua tim adalah mendapatkan angka dengan memasukkan bola kekeranjang lawan dan mencegah lawan memasukan bola ke keranjang kita. Permainan bola basket diawasi oleh officials (wasit), tableofficials, dan seorang commisioner (pengawas pertandingan). 
10 | Fajar Muhammad Faturahman ${ }^{1 *}$, Beny Iskandar ${ }^{2}$,Eneng Fitri Amalia ${ }^{\mathbf{3}}$

Peningkatan Hasil Belajar Lay Up Bola Basket Melalui Metode Mengajar Bagian

Dalam upaya meningkatkan
capaian pembelajaran dan prestasi
dicabang olahraga bola basket, banyak
faktor-faktor yang berkaitan. Pada saat ini
dalam pembelajaran materi bola basket di SMP Negeri 1 Warungkondang belum sepenuhnya berjalan dengan baik, sehingga pencapaian pembelajaran dan prestasipun belum seperti yang diharapkan, untuk mencapai hal tersebut dibutuhkan berbagai hal seperti minat, bakat, kondisi fisik, sarana, prasarana, serta suatu sistem latihan yang disebut metode.

\section{METODE}

Metodologi penelitian merupakan suatu cara ilmiah yang digunakan oleh peneliti dalam melakukan penelitian untuk mendapatkan data untuk tujuan tertentu. (Mela Aryani, 2018:12).

\section{JENIS PENELITIAN}

Metode yang digunakan dalam penelitian ini adalah Penelitian Tindakan Kelas (PTK). Menurut Aqib (2007:13) Penelitian tindakan kelas merupakan suatu pencermatan terhadap kegiatan belajar berupa sebuah tindakan yang disengaja dimunculkan yang terjadi dalam sebuah kelas secara bersama.

\section{POPULASI DAN SAMPEL}

Penelitian ini dilaksanakan di SMP Negeri 1 Warungkondang yang terletak di Kecamatan Warungkondang, Kabupaten Cianjur . Penelitian ini dilaksanakan pada pertengahan semester genap tahun pelajaran 2018-2019, yaitu bulan Maret sampai Mei 2019. Penentuan waktu penelitian mengacu pada kalender akademik sekolah, program tahunan sekolah dan program semester sekolah. Dalam Penelitian tindakan kelas ini yang dijadikan sebagai subjek adalah siswa kelas VII-8 dari seluruh populasi kelas VII di SMP Negeri 1 Warungkondang tahun ajaran 2018-2019 dengan jumlah siswa 32 orang, terdiri atas 14 siswa laki-laki dan 18 siswa perempuan.

\section{TEKNIK PENGUMPULAN DATA}

Pengumpulan data dilakukan menggunakan cara tes dan observasi secara langung pada sampel penelitian. Instrumen penelitian yang digunakan adalah tes lay up bola basket yang dikemukakan oleh Yadav dalam Nurhasan dkk. (2017:224) yaitu Siswa berdiri di belakang garis free throw, setelah aba-aba "ya" siswa mengambil bola yang berada di kursi sebelah kanan, kemudian siswa mendribble bola kemudian melakukan lay up shoot. Setelah melakukan lay up shoot, siswa menangkap bola tersebut lalu mengoper bola tersebut kepada temannya yang berada di belakang kursi sebelah kanan. Setelah itu siswa mengambil bola dari kursi sebelah kiri kemudian melakukan lay up shoot kembali ke arah ring basket, lalu menangkap bola tersebut dan mengoper ke pada temannya yang berada di belakang kursi sebelah kiri. Siswa berusaha memasukkan bola 
11 | Fajar Muhammad Faturahman ${ }^{1^{*}}$, Beny Iskandar ${ }^{2}$,Eneng Fitri Amalia ${ }^{3}$

Peningkatan Hasil Belajar Lay Up Bola Basket Melalui Metode Mengajar Bagian

sebanyak mungkin ke dalam ring basket dalam waktu 1 menit. penghitungan Skor dilakukan dengan cara mendapatkan skor 1 apabila siswa melakukan gerakan lay up shoot dengan benar dan bola masuk. Mendapatkan skor 0 apabila siswa tersebut melakukan kesalahan dribble (double, traveling) atau bola tidak masuk.

\section{ANALISA DATA}

Teknik analisis data yang digunakan adalah analisis data kualitatif dan kuantitatif.

\section{HASIL dan PEMBAHASAN}

Setelah peneliti melaksanakan tes pra siklus, peneliti menganalisis dari tes tersebut mendapatkan hasil tes pra siklus atau kondisi awal diperoleh hasil poin tertingi dari kesuluhan siswa adalah 5 dan terendah adalah 0 dengan nilai rata-rata 20,9 dari pencapaian nilai maksimal 100 . Persentasi ketuntasan yang dilihat dari kodisi awal ditafsir mencapai $3,12 \%$. Ini mengindikasikan bahwa hasil pembelajaran masih jauh dari kata berhasil, hasil tersebut juga dapat dilihat pada diagram berikut:

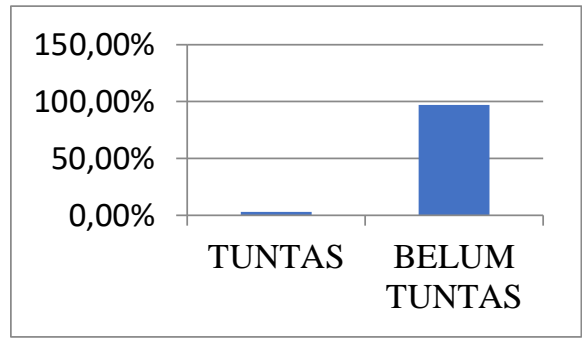

Diagaram 1.

Persentase Nilai Keterampilan Teknik Lay up (Pra Siklus)
Dengan melihat hasil yang dicapai pada pra siklus dan hasil refleksi dapat disimpulkan bahwa hasil pembelajaran belum sesuai yang diharapkan. Hal ini disebabkan karena pembelajaran siswa masih menggunakan metode yang kurang tepat dan kurang terstruktur serta dalam proses pembelajaran masih ada kekurangan yaitu dalam pengolahan waktu serta sarana dan media pembelajaran yang kurang dan dapat dikatakan kurang bervariasi, sehingga guru memberikan penjelasan dan bimbingan pada peserta didik terkesan tergesa-gesa, akibatnya tujuan pembelajaran tidak tercapai sebagaimana mestinya. Pengolahan waktu serta sarana atau media pembelajaran yang kurang baik mengakibatkan guru tidak dapat membimbing siswa dengan baik dalam melaksanakan pembelajaran.

\section{Siklus I}

\section{Hasil observasi terhadap siswa}

Dari analisis lembar observasi terhadap siswa diperoleh data-data, hasil pembelajaran belum berjalan seperti yang diaharapkan. Itu disebabkan karena beberapa faktor salah satunya yaitu masih ada beberapa siswa yang kurang memperhatikan ketika guru menjelaskan materi tenik lay up serta masih ada beberapa siswa yang belum dapat menjawab pertanyaan guru seputar teknik lay up serta beberapa siswa yang kurang serius mengikuti pembelajaran. Hal itu diperkuat ketika melakukan praktek lay up 
12 | Fajar Muhammad Faturahman ${ }^{1^{*}}$, Beny Iskandar ${ }^{2}$,Eneng Fitri Amalia ${ }^{\mathbf{3}}$

Peningkatan Hasil Belajar Lay Up Bola Basket Melalui Metode Mengajar Bagian

sebagian siswa belum dapat melakukannya dengan baik.

\section{Hasil belajar}

Berdasarkan hasil tes sikus I diperoleh hasil nilai tertinggi 7 dan nilai terendah 2 dengan nilai rata-rata 48,75 dari pencapaian maksimal 100. Persentasi ketuntasan yang dilihat dari siklus I mencapai $21,87 \%$. Ini mengindikasikan bahwa hasil pembelajaran belum dapat sepenuhnya dikatakan baik walaupun sudah lebih baik jika dibandingkan dengan hasil tes pra siklus. Hasil tersebut juga dapat dilihat pada diagram berikut:

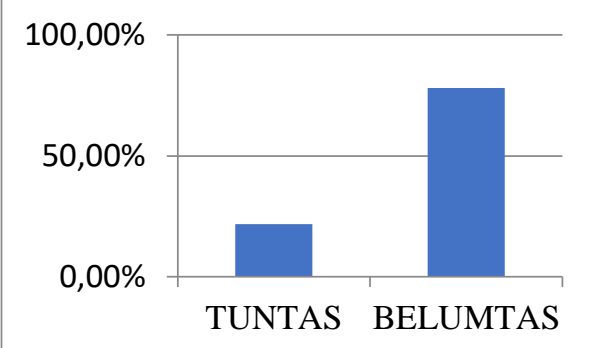

Diagram 2.

Persentase Nilai Keterampilan Teknik

\section{Lay up Siklus I}

\section{Evaluasi dan refleksi}

Berdasarkan hasil pengamatan terhadap siswa dan hasil evaluasi dapat deketahui bahwa pada siklus I belum dapat dikatakan berhasil karena masih ada siswa yang belum memperoleh nilai diatas nilai ketuntasan minimal.

Dengan melihat hasil yang sudah dicapai pada siklus I dan hasil refleksi, dapat diketahui pembelajaran di dalam setiap kelompok belum berjalan dengan baik serta penguasaan siswa dalam melakukan teknik dasar lay up serta dalam pembelajaran menggunakan metode bagian belum berjalan dengan baik, dan dalam proses pembelajaran masih ada kekurangan yaitu pengelolaan waktu dengan baik sehingga pada saat memberikan penjelasan dan bimbingan terkesan tergesa-gesa serta pemanfaatan media alat-alat bantu yang belum baik cara penggunaannya. Akibatnya, tujuan pembelajaran tidak tercapai seperti yang diharapkan.

Disamping faktor diatas, ada faktor lain yang mempengaruhi yaitu masih banyak siswa yang kurang antusias dalam prosespembelajaran, sehingga ketika pada pemaparan petunjuk pelaksanaan tidak menangkap secara baik materi yang disampaikan dan pelaksanaannya pun terhambat karena kualitas tekniknya masih belum cukup baik.

\section{Siklus II}

\section{Hasil observasi terhadap siswa}

Berdasarkan hasil observasi terhadap siswa diperoleh hasil sebagai berikut:

Siswa meningkatkan kemampuan lompatan dalam melakukan teknik lay up melalui metode bagian. dalam kelompoknya, maupun pada saat tes sudah menunjukan adanya peningkatan.

Kerjasama antar siswa sudah membaik dalam meningkatkan keterampilan teknik lay up melalui metode bagian 
13 | Fajar Muhammad Faturahman ${ }^{1 *}$, Beny Iskandar ${ }^{2}$, Eneng Fitri Amalia $^{3}$

Peningkatan Hasil Belajar Lay Up Bola Basket Melalui Metode Mengajar Bagian

Keberanian siswa dalam melakukan tes teknik lay up sudah ada peningkatan.

Siswa sudah menguasai teknik lay up melaui metode bagiandalam upaya meningkatkan gerakan tangan dan lompatan pada teknik lay up.

Siswa sudah mampu melakukan koordinasi gerakan lay up yang baik melalui metode bagian.

\section{Hasil belajar}

Berdasarkan hasil tes siklus II diperoleh hasil untuk poin tertinggi 7 dan poin terendah 3dengan nilai rata-rata 73,1 dari nilai maksimal pencapaian 100 . Presentase ketuntasan ditafsir mencapai $81,25 \%$, ini menunjukkan hasil tes teknik lay up bola basket melaui metode bagian. berjalan dengan baik. Hal tersebut juga dapat dilihat dari diagram berikut:

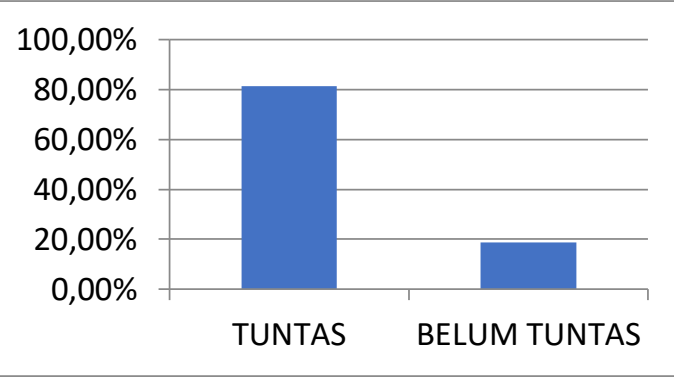

Diagram 3.

Persentase Nilai Keterampilan Teknik

Lay up Siklus II

\section{Evaluasi (Reflecting)}

Peneliti melakukan refleksitehadap pelaksanaan siklus ke II dan menganalisis untuk membuat kesimpulan atas pelaksanaan peningkatan keterampilan teknik dasar lay up bola basket melaui metode bagian di SMP Negeri 1 Warungkondang Kecamatan Warungkondang Kabupaten Cianjur.

Dari hasil kajian pada pelaksanaan terhadap siklus II menunjukkan adanya peningkatan keterampilan teknik lay up bola basket. Pada siklus I persentase skor untuk observasi siswa $71,8 \%$, Sedangkan pada siklus II persentase skor untuk observasi siswa $88,15 \%$.

Peningkatan ini disebabkan karena masing-masing individu pada saat proses pembelajaran menggunakan metode bagian untuk meningkatkan keterampilan teknik lay up bola basket, siswa melaksanakan pembelajarannya dengan sungguh-sungguh dan penuh percaya diri.

Berdasarkan hasil pengamatan terhadap guru, hasil pengamatan siswa dan hasil evaluasi dapat diketahui bahwa pada siklus II sudah dapat dikatakan berhasil karena banyak siswa yang memperoleh nilai di atas nilai ketuntasan minimal, sehingga rata-rata siswa sudah mencapai batas.

Dan hasilpenelitian ini, diperoleh nilai siswa pada kelas VII-8 SMP Negeri 1 Warungkondang dapat digambarkan sebagai berikut pada diagram 4. yaitu kenaikan persentase ketuntasan rata-rata pada tiap siklus. 


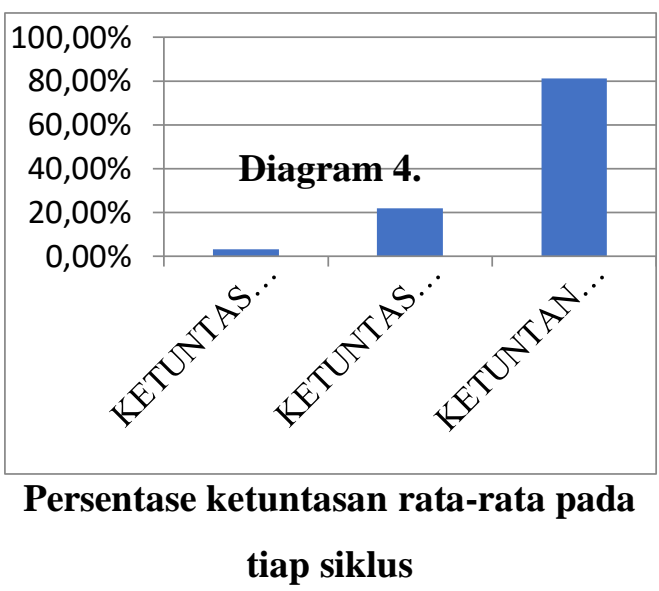

Dari diagram 4.4 terlihat kenaikan keterampilan teknik lay up, data ini diperoleh dari analisis hasil tes dari tiap siklus. Dari hasil analisis tersebut, maka sudah diketahui bahwa peningkatan keterampilan teknik lay up bola basket melalui metode bagian sudah ada peningkatan.

\section{Pembahasan}

Setelah dilakukan pengolahan dan analisis terhadap data hasil penelitian, maka pada bagian ini akan dibahas mengenai hasil dan temuan penelitian. Pembahasan tersebut akan difokuskan pada permasalah yang sebelumnya telah dijelaskan pada bab I.

Hasil pembelajaran keterampilan teknik dasar lay up bola basket melui metode bagianmengalami peningkatan pada tiap siklusnya. Untuk hasil belajar pra siklus (kondisi awal) rata-rata nilai tes evaluasi adalah 20,9 dari pencapaian nilai maksimal 100 hal ini terjadi dikarenakan kemampuan siswa dalam melakukan keterampilan tekinik lay up masih sangat minim baik dari segi melangkah, lompatan, gerakan tangan maupun hasilnya serta peran guru dalam pengelolaan waktu yang sepenuhnya belum berjalan dengan baik sehingga pada saat melaksanakan dan melakukan bimbingan terhadap siswa terkesan tergesa-gesa, namun hal itu juga disebabkan oleh guru masih sangat minim dan tidak cukup menunjang lebih jauh kemampuan siswa dalam proses pembelajaran teknik lay up pada bola basket.

Pada siklus I rata-rata nilai tes atau evaluasi keseluruhan adalah 48,75 hal ini terjadi karena siswa pada saat melaksanakan proses pembelajaran teknik lay up melalui metode bagian. belum berjalan dengan baik, sehingga penguasaan materi masih kurang dipahami oleh siswa akibatnya, pada saat melakukan tes atau evaluasi mereka belum dapat melakukan keterampilan teknik lay up bola basket dengan cukup baik dan benar secara teknik maupun hasilnya.

Pada siklus II nilai rata-rata siswa meningkat drastis menjadi 73,1 dari pencapaian nilai maksimal 100. Hal ini menunjukkan bahwa siswa sudah mulai terbiasa dengan pembelajaran teknik lay up melalui metode bagian, Sehingga pengetahuan yang diperoleh pun menjadi meningkat dan pada saat melaksanakan tes atau evaluasi sebagian besar siswa dapat melakukan keterampilan teknik lay up pada bola basket baik secara teknik maupun hasilnya.

Aktivitas siswa selama proses pembelajaran dapat dilihat berdasarkan 
15 | Fajar Muhammad Faturahman ${ }^{1^{*}}$, Beny Iskandar ${ }^{2}$,Eneng Fitri Amalia ${ }^{\mathbf{3}}$

Peningkatan Hasil Belajar Lay Up Bola Basket Melalui Metode Mengajar Bagian

hasil lembar observasi terhadap aktivitas pembelajaran siswa. Penilian ini dilakukan pada saat siswa melalukan pembelajaran serta pembelajaran dilakukan dengan cara siswa dibentuk menjadi dua kelompok untuk melaksanakan proses pembelajaran melalui metode bagian.

Pembelajaran berkelompok dalam meningkatkan keterampilan teknik lay up melalui metode bagian merupakan hal yang baru bagi siswa dalam hal ini mampu menciptakan minat dan tanggapan yang positif dari siswa dimana pembelajaran sebelumnya guru hanya menggunakan pembelajaran secara klasikal, yaitu pembelajaran yang berspusat pada guru dan pemanfaatan peralatan yang dapat dimodifikasi. Pada saat pembelajaran siswa sangat senang karena pembelajaran dilakukan dengan berbeda dari biasanya, sehingga dapat menimbulkan rasa ceria, senang, disiplin, dan penuh rasa tanggung jawab dalam melakssanakan pembelajaran, selain itu guru memeberikan motivasi yang sangat besar yang menjadikan siswa menyukai mata pelajaran pendidikan jasmani dan siswa menginginkan materi dengan diajarkan dengan metode seperti ini.

Dalam hasil observasi, siswa merasa bahwa pembelajaran menggunakan metode bagian untuk meningkatkan keterampilan teknik lay up bola basket dapat memberikan kemudahan dalam memahami materi karena dilakukan secara bagian dan bertahap, dibandingkan dengan pembelajaran sebelumnya yang kurang dalam variasi pembelajaran. Walaupun pembelajaran berpusat pada siswa, akan tetapi guru mempunyai arti penting sebagai fasilitator dan mediator yang mengarahkan siswa pada jawaban yang benar dan motivator yang selalu memotivasi untuk berpartisipasi aktif selama pembelajaran berlangsung.

Pembelajaran pendidikan jasmani khususnya dalam peningkatan keterapilan teknik lay up bola basket melaui metode bagian ini umumnya sesuai dengan rencana dan tujuan yang diinginkan. Secara umum pembelajaran dengan menggunakan metode bagian ini efektif dan memberikan kontribusi yang berarti dalam meningkatkan keterampilan teknik lay up pada permainan bola basket.

\section{SIMPULAN}

Berdasarkan hasil penelitian, terbukti bahwa adanya peningkatan hasil belajar lay up melalui metode bagian dengan persentase peningkatatan ketuntasan nilai siswa tiap siklus sebagai berikut : Pretest : 3,12 \%, Siklus I : 21,87 $\%$, Siklus II : 81,25\%.

\section{DAFTAR PUSTAKA}

Amber, Vic. (2009). Petunjuk Untuk Pelatih dan PemainBola Basket. Bandung. Pionir Jaya.

Aryani, Mela. (2018). Metodologi Penelitian Pendidikan Jasmani \& Olahraga. Universitas 
16 | Fajar Muhammad Faturahman ${ }^{1 *}$, Beny Iskandar ${ }^{2}$,Eneng Fitri Amalia ${ }^{3}$

Peningkatan Hasil Belajar Lay Up Bola Basket Melalui Metode Mengajar Bagian

Suryakancana.Cianjur. Tidak

Diterbitkan.

MS Taufik, MG Gaos ..., 2019

Peningkatan Hasil Belajar

Dribbling Sepakbola Dengan

Penggunaan Media Audio Visual

Jp. Jok (Jurnal Pendidikan

Jasmani, Olahraga dan kesehatan

MS. TAUFIK, (2018) Meningkatkan

Teknik Dasar Dribbling Sepakbola

Melalui Modifikasi Permainan
Jurnal Maenpo Jilid 8 Terbitan

JUNI 2018 Halaman 2

Aqib, Zainal. (2007). Penelitian Tindakan

Kelas. Bandung. Margalaya

Permai.

Nurhasan, dkk. (2017). Tes, Pengukuran dan Evaluasi dalam Pendidikan Jasmani dan Olahraga. Universitas Suryakancana. Cianjur. Tidak Diterbitkan. 